\title{
The Governance of Water Use in Northwest Mexico: A Qualitative and Quantitative Based Study
}

\author{
Ricardo V. Santes-Alvarez (PhD) \\ Department of Urban and Environmental Studies \\ El Colegio de la Frontera Norte, Mexico
}

Doi: 10.19044/esj.2017.v13n29p68 URL:http://dx.doi.org/10.19044/esj.2017.v13n29p68

\begin{abstract}
In Mexico, the working of government institutions lags far behind the aims of good governance and sustainable development. Institutions deviate from those goals when they circumvent their duties to general wellbeing to favour powerful interest groups. The issue is even more of a concern in lands of high economic value, where the competition for water is strong. San Quintin Region, in the arid northwest part of the country, is symbolic; it is a rich agro-productive area inserted in the international market from way back, yet its economic success contrasts with worries regarding social conflict and environmental decline due to water misuse. Allegedly, if current exploitation trends remain unchanged, the viability of the ecosystem as a whole will be at risk soon.

In this article, it is argued that the administration and management of water runs up against the aims of sustainable development; hence, measures to improve governance are needed. The main objective was to investigate the institutional and social context in which the problem occurs, so as to unveil the prospects of improvement. A qualitative and quantitative methodology suggested that in San Quintin, governance of water use reflects dubious institutional workings. It is unjust, because it fosters an inequitable treatment of the local population; also, it is environmentally damaging in view of the overexploitation of extant resources, often to the point of depletion. Furthermore, water use lacks context-focus, due to the centralised decisionmaking process. All in all, governance might progress through decisive reforms to social and institutional practices.
\end{abstract}

Keywords: Water governance, Institutional working, Qualitativequantitative analysis, San Quintin Region, Mexico 


\section{Introduction}

In developing countries, the central governments keep control of the policy and decision-making apparatus as a rule; therefore, although they may argue they privilege economic growth for all, the reality is that overwhelmingly, policies are designed to favour certain powerful interest groups. Governments favour the market opening and privatisation proposals that are promoted by transnational financial organisations, but put social and environmental aims aside. Regional and local governments proceed according to the central government's ruling (Evans, 1989; Greer \& Singh, 2000; Shah et al., 2004; Ngosso, 2013), regardless of the negative effects that those instructions might have on specific areas or systems. The "environmental issues", which are not only environmental, are set aside from mainstream public policy. The opinion that government and elite groups prefer a for-profit approach with regard to public affairs permeates the discourse about development and sustainability; it provokes discontent among those in many sectors of society, who think that authorities and bureaucracies implement non-economic policies wrongly on purpose. The immediate proof of such behaviour seem to be social injustice and environmental damage.

The San Quintin Region, a rich agro-productive area in the arid northwest of Mexico, is a case in point. Its economic activity serves the interests of a few at the expense of the general population and the environment (Cruz-Aguirre, 2009; Ruiz, 2014), because its maintenance is based on overexploitation of hydrologic resources, and the unequal apportionment of water for domestic and other uses. Such practices cause deterioration and depletion of aquifers, and social anxiety. Environmental issues in San Quintin are thus defined as physical and biological matters enmeshed with social unease; that is why solutions demand technical as well as political approaches. Alternatively, in the case where current water usage is maintained, the viability of the ecosystem as a whole will be at risk soon.

This article argues that the administration and management of water in the region runs against the aims of sustainable development; improved governance is needed to change the situation. Its objective is to examine the institutional and social context in which the problem occurs, so as to elucidate the prospects of change. Specifically, I intend to: (1) identify the factors that contribute to current practices, (2) disclose the determinants of present conditions, and (3) advance the betterment of water use governance. To those ends, a qualitative and quantitative methodology which is useful to examine the institutional framework, and attitudes of key actors, was utilized.

The next part of the article offers a theoretical approach to the governance of water use; it takes hold of the economic rationale perspective 
and the institutional plan followed by Mexico regarding the issue; the third section refers to materials and methods, including a description of the study area; the fourth part presents the obtained results. The fifth one presents a discussion of the findings, and the sixth part reflects on the alternatives for the betterment of governance in the region. The article closes by presenting conclusions and suggestions for further research.

\section{Water governance}

\section{The economic rationale}

In a global perspective, the story of development and sustainability leans decisively towards the motivation of revenue, where the idea of unlimited production and consumption of goods based on "intensive accumulation" is common (Spangenberg, 2006; Schlesinger, 2008, p. 102). Humanist thinkers (Cruz-Souza, 2007, pp. 93-94; Talavera, 2014) disagree with this motivation that some call the "neoliberal economism perspective," since it contains the seeds of social inequality. Therefore, unlimited production and consumption are judged to be justifiable by some but inappropriate by others. (Oka \& Kuijt, 2014); nevertheless, economic return is inseparable from market-oriented policy. Public programmes, strategies and bureaucracies that respond to economic targets only eventually result in harmful outcomes: destruction of natural resources, impoverishment of territories, and expulsion of the population involved in agriculture (Segrelles, 2001; Cruz-Souza, 2007, p. 99).

In the developing world, it is common to find negative consequences of the for-profit approach to an extreme degree. There, the promotion of profits is the only goal pursued in a serious way by national governments; it is far more of a priority than conservation of nature or social welfare. National governments welcome market and privatisation directives from international organisations; they favour wealthy entrepreneurs in natural resource management, and open the door to transnational corporations. Governments do not care whether they set aside the needs and demands of local residents (Evans, 1989; Mussetta, 2013); they are the architects of two confronted goals: to privilege economic efficiency, and to support the livelihoods of the poorest (Molle \& Wester, 2009, p. 17).

In a context where government favours powerful interest groups, the rights and freedoms of others are affected. To accommodate the interests of the influential above those of the many, it is necessary to depart from concepts of professional integrity and ethics (Wengert, 1971). Accommodation acquires thus a negative connotation, because what is thought to be correct, just, and rational becomes compromised by misconduct of public servants. Such a scenario reveals an inadequate, 
permissive institutional design, to which authorities and bureaucracies accommodate suspiciously.

Governance of water use illustrates the issue. Its perception as profitable has been upheld in international forums, the most germane being the International Conference on Water and the Environment, held in Dublin, in January 1992. There, the idea that an economic perspective would serve to maximize efficiency and promote water conservation was welcomed (United Nations, 1992; Wilder, 2010). The implicit reasoning in Principle 4 of The Dublin Statement was that privatization of water services meant better management compared to traditional state control, which is very centralised, conservative, and inefficient (Wilder, 2010).

The Dublin conference overlooked the concept of water as a social good; nevertheless, the discussion continued. In 2002, the United Nations Covenant on Economic, Social and Cultural Rights stressed its vital importance, assuring that it is "a limited resource and a public good that is fundamental for life and health"; in addition, the Covenant maintained that the human right to water is essential for a decent life (United Nations, 2003). In 2010, the General Assembly issued a specific resolution regarding the human right to water and sanitation (United Nations, 2010); thereafter, the functions recognised by the international community put water in a dimension much broader than mere accumulation. It is crucial to life on earth and cannot be viewed only in terms of profit.

In developing countries, though, the principles of the international agenda are put into action surreptitiously, mostly, to favour powerful interests; nevertheless, social opposition reveals how erroneous such measures can be. Various well-known imbroglios in Latin America, such as the Water War in Bolivia and other experiences (Santos \& Villarreal, 2005) attest to the failure of governmental decisions and private sector interventions in water management when they lack social support.

\section{Institutional approaches in Mexico}

Governance of water in Mexico has followed the mainstream pattern. The National Water Law (NWL) of 1992 reflected the administrative philosophy of the so-called New Public Management (NPM) approach, since one of its goals was to increase the participation of local government, water users and the private sector in water management (Eakin et al., 2011). However, it soon encountered strong resistance in the field; water governance in the country is tied to ancient inertias, such as centralisation of decisions, technical and administrative barriers, and doubtful performance of responsible authorities.

The NWL purports to achieve integral sustainable development by means of regulating the use, distribution, and control of water, as well as 
preserving its quantity and quality (Gov. of Mexico, 2012a). Arguably, to that end, its administration and management is a federal responsibility; hence, the Ministry of Environment and Natural Resources (Semarnat), through the National Commission on Water (CNA), is the related authority (Gov. of Mexico, 2012b). Broadly, the bureaucracy implements policies, strategies, programmes and actions, pledging to determine availability, operate infrastructure, preserve aquifers, and ensure the quality of surface water. It also grants concessions, allowances, and permits, and supposedly resolves conflicts on the matter (Santes-Álvarez, 2015a, pp. 30-32).

Due to their encompassing mandates, the NWL, and the activities of CNA raise concerns and criticisms. The law empowers the federal government only; therefore, despite the local governments' participation in Water Councils to discuss issues about specific watersheds, they lack authority to make decisions. The law also encourages the overexploitation of natural reservoirs because enhancing the offer and circumventing the demand side favours a culture of high consumption and mismanagement (Garavito, 2010, p. 30). In its turn, CNA generates more problems than solutions; among the alleged drawbacks, the more salient are centralisation of decisions, technical and administrative barriers, lack of intergovernmental coordination, red tape in the operation of basin organisations, and dubious practices. The latter include over-authorization of concessions, unclear statements on water use, and corruption in the transference of rights. The authority shows further deficiencies: its duties of protecting aquifers and monitoring the quality of water were only marginal. Its obligation to prevent and take care of possible conflicts is irrelevant as well; rather, its unreflective granting of concessions, assignments, and permits encourages anger among stakeholders (Zomosa, 2007; Hurtado, 2012; Santes-Álvarez, 2015a, p. 33).

Wilder (2010) stresses that, bearing in mind the tenets of marketization, decentralisation, and sustainability, Mexico pioneered a series of transformations in water policy. The first purpose was achieved to some extent, although the others barely evolved or remained at the level of political discourse. The River Basin Councils or the Technical Committee on Underground Water might be sympathetic to decentralisation and sustainability as long as they propose the participation of local governments and citizens in administration; nevertheless, they are strongly constrained by the central government. The federal authority retains key strategic functions, and leaves only "soft", daily operations to its local counterparts (Wilder, 2010).

Additional directives, which supposedly would commit the country to "a more democratized water management paradigm" (Wilder, 2010), emanated from further reforms to the NWL in 2004; however, progress in the field was hindered, mainly because the structural problems within the 
Mexican bureaucracy remained unsolved. It is worth noting that the essential components of the NPM-granting more autonomy to public agencies and government officials, and using market mechanisms to promote competition in the public sector-have since always been absent from Mexico's political agenda (Cejudo, 2008). The decentralisation process that would have resulted from NPM autonomy policies barely meant the transfer of responsibilities to local authorities, and the goal of competing in the public sector was substituted for by privatisation. In this regard, privatisation was heightened in January 2012 (Gov. of Mexico, 2012c), with the enactment of the Federal Law of Public-Private Partnership, which allowed the insertion of private capital in the development of public infrastructure and services.

In the state of Baja California, the enactment of the Public-Private Partnership Law in 2014 and the Water Law of December 2016 meant absolute consent for the participation of the private sector in water infrastructure projects and services (Gov. of Baja California, 2014; 2016). It is noteworthy that the state water law sparked outraged social protest, because among its most worrying provisos, it opened the door to the private administration of drinkable water, the increase and liberalisation of tariffs, and the total suppression of services in case of non-payment. Because of such unpopular provisos, social unrest escalated, up to the point that the state Governor had no choice other than to abrogate the law in January 2017. Despite that unrest, privatisation of water projects remains at the top of the political agenda.

\section{Materials and Methods \\ Study area}

Located in the state of Baja California, $150 \mathrm{~km}$ south of the municipality of Ensenada, San Quintin Region (SQR) expands in an eastwest direction from the highest mountains of Sierra San Pedro Martir down to the Pacific, whilst in a north-south direction it goes from coordinate $31^{\circ} 06^{\prime} 00^{\prime \prime} \mathrm{N}$ to coordinate $29^{\circ} 48^{\prime} 00^{\prime}$ ' N. In geopolitical terms, it consists of the four administrative delegations of Ensenada, namely Camalu, Vicente Guerrero, San Quintin, and El Rosario (Figure 1). Its area is around 10,000 $\mathrm{km}^{2}$, which represents 14 percent of the state surface $\left(71,450 \mathrm{~km}^{2}\right)$. Its population of nearly 92000 in 2010 represented $2.9 \%$ of the state $(3.16$ million) population (Gov. of Baja California, 2003a; Coplade, 2013; Gov. of Ensenada, 2014, p. 96; INEGI, 2015; Riemann, 2015). 


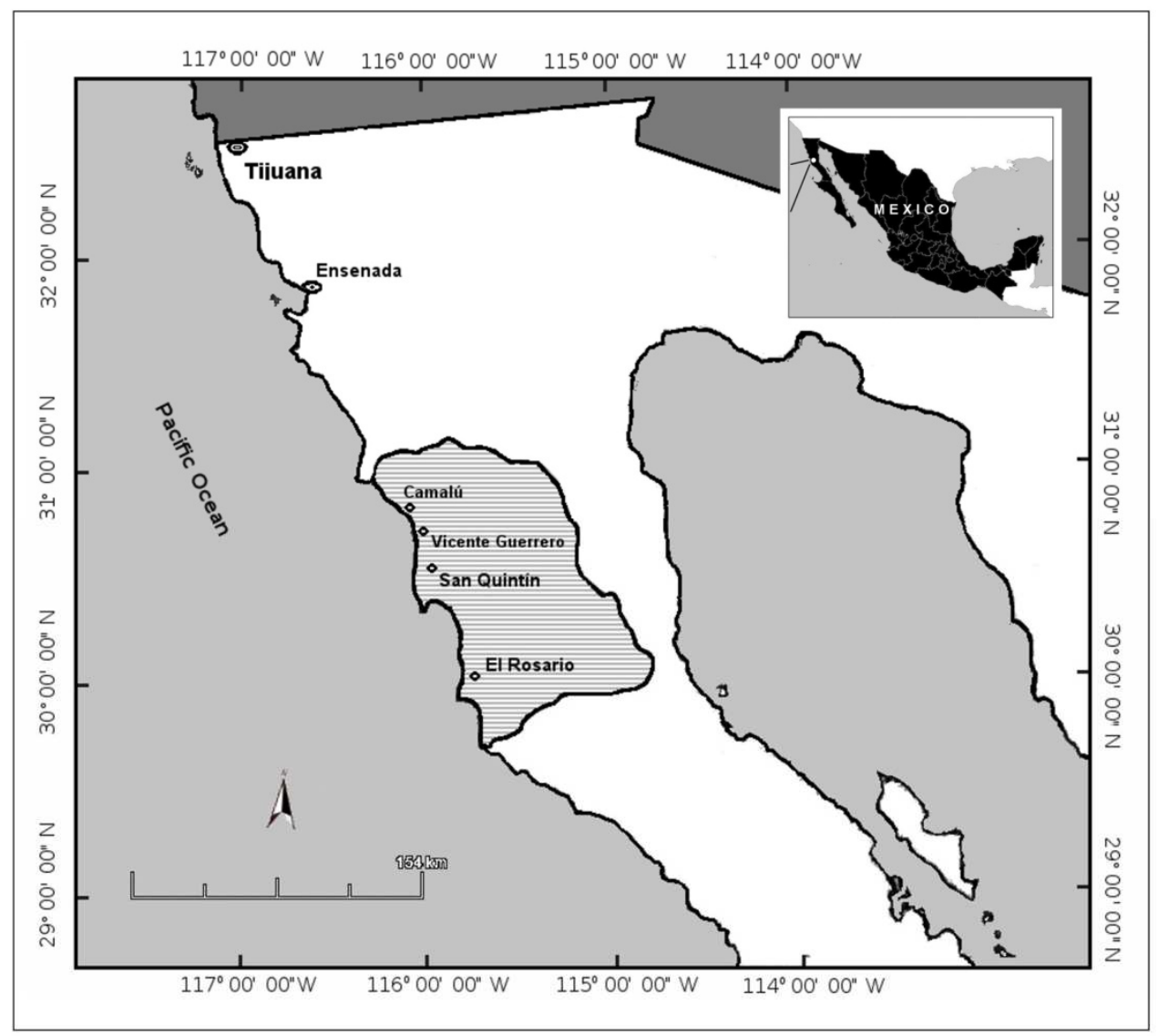

Figure 1. San Quintin Region, in Baja California, Mexico

The economically active population has been engaged principally in the primary sector, whereas the rest has concentrated in construction and services (oscillating between percentages of about 49-55, 12-10 and 39-35, respectively) (Gov. of Baja California, 2003a, p. 62; 2008, p. 11). In terms of Gross Domestic Product, in 2011, the primary, secondary and tertiary sectors represented percentages of 63, 3, and 34, respectively (Gov. of Ensenada, 2014).

The region enjoys a benign Mediterranean climate amidst arid lands, with the lowest national year-round precipitation figures and no relevant surface streams; thus, SQR is well-valued land. A great deal of the state's economic activities are present there, the most important being the production of horticultural crops, especially vegetables and fruits cultivated in open fields and greenhouses for exportation. In terms of cultivated area and production costs, the main crops are tomatoes, onions, cucumbers, strawberries, raspberries, sprouts, broccoli, celery, and zucchini (Lizárraga, 1997; Zlolniski, 2011, p. 569; Gov. of Ensenada, 2011; 2014, pp. 43-44). 
The economic dynamics in SQR has triggered a wide spectrum of problems. From different perspectives, a number of scholars (Lizárraga, 1997; Hernández, 2000; Zlolniski, 2011; Velasco, et al., 2014; Riemann, 2015; Santes-Álvarez, 2015b; 2016) have studied the area, examining complex social, economic, political, and environmental conditions. Despite the profitable character of agro-production, studies show that the region faces negative outcomes; during the last decades, difficulties in accessing the key resource of water have increased because its availability is reaching critical levels. Surface streams are irrelevant, active only during the rainy season (CNA, 2002), so underground reservoirs are the main sources. Currently, however, most aquifers are depleting, since extraction is surpassing their recharging capacity. A further consequence of this trend is the salting of underground reservoirs due to the intrusion of brackish water entering from the San Quintin Bay.

The situation has been aggravated due to extensive use of land for agriculture and urban development, which obviously demands more water (CNA, 2002; Gov. of Baja California, 2007). Additionally, through inadequate manipulation of agrochemicals (pesticides, herbicides, fungicides), agriculture causes acute socio-environmental impacts such as human diseases and contamination of soils (Zúñiga et al., 2012). Even worse, chemicals infiltrate soils and contaminate the aquifers.

There is unrest in the region regarding management of water. The responsible federal agency distributes the liquid unevenly, and the greatest proportion (almost 93\%) goes to agro-production (Riemann, 2015), whereas the rest is left to domestic and other uses. Such a figure is relevant because, considering that at the national and state levels the average apportionment of water to agriculture is nearly $76 \%$ and $82 \%$, respectively (CNA, 2014), the disparity in SQR is obvious. The distribution of the water shows an excessive support of agribusiness; in contrast, in urbanised or semi-urbanised areas, the local authority provides insufficient volumes and related infrastructure for domestic and sanitation purposes; the poor residents, mostly indigenous people, are the first to be excluded from access to basic services (Zlolniski, 2011). It turns out that water stress-that is, the symptom of scarcity among the population-appears in the context of structural (physical and economic) constraints. It is noteworthy that inadequate policy and institutional design make the profit factors more determinative in pushing the region towards critical limits.

In SQR, therefore, social and environmental concerns, and a pessimistic view of the ecosystem, contribute to the condition of inappropriate water use governance (Gov. of Baja California, 2003b, p. 35). The responsible bureaucracies act inappropriately because, by favouring the agribusiness sector, they pay less attention to the rest of the population and 
tolerate overexploitation of the existent aquifers, for long the sole available sources. In addition, public organisations cater to a conventional scheme of centralised decision-making, which falls short in terms of understanding the region specificities and in giving subnational governments the necessary legal and administrative strength. In the end, the disagreement or even confrontation among stakeholders, and environmental damage, are the more objectionable outcomes. Governments at different levels acknowledged the relevance of the issue long ago, and argued they were attempting to arrive at a solution (Gov. of Baja California, 2003a, pp. 52-53); nevertheless, no action has been effectively deployed in the field. On the contrary, when a desire emerged among the region's residents for San Quintin to become a new municipality -in order to acquire some degree of political and economic autonomy-, and the initiative was approved by the state Congress in June 2013, former Governor Osuna immediately vetoed the resolution alleging legal faults (Gov. of Baja California, 2015). Therefore, the problem remains and increases.

\section{Methodology}

During the summer of 2013, the author conducted research on the general characteristics, as well as on water usage, in SQR. Cabinet and field surveys served to compile the inputs for the analysis. Collection and ordination of data continued until the first quarter of 2016. Interviews with key actors served to collect perceptions about current conditions, explanations of problems, as well as proposals for the improvement of governance in the region. The qualitative and quantitative examination that followed, here labelled as TMNet method, envisioned to recognise relationships among the characteristics that define the governance of water use. It comprises three procedures: textual, multivariate (cluster), and network analyses.

\section{Textual Analysis}

The word crunching of documents made it possible to build a list of expressions representing actors, public establishments, or topics. In a second stage of the analysis, expressions were useful to generate a co-occurrence matrix. Atlas-ti software (v 7.1.5) served this purpose.

\section{Cluster Analysis}

Cluster Analysis (CA) belongs to a family of exploratory techniques useful to find hierarchical groups in multivariate categorical data sets. It produces a "dendrogram" showing how data points cluster, or how they group or associate. The unweighted pair-group average algorithm was adequate to join clusters based on the average distance between all members 
of two groups. Because the procedure relied on counted data, the Morisita Index assisted in computing the distance matrix. The PAST (v 3.11) software served to perform the test.

\section{Network Analysis}

Network Analysis (NA) helped to find meaningful relationships and distinguishing relevancies among nodes. Two aspects were determinative to setting a hierarchical configuration of nodes in the network: Degree and Weight. The first indicates the number of connections with others that a specific node exhibits, whilst the second specifies the strength of the connection with any other node in the network that a specific node has. Gephi software (v 0.9.1) was provided to address NA.

\section{Results}

\section{Textual examination}

The word crunching procedure resulted in a list of thousands of terms; therefore, a set of criteria -essentially all words related to water use filtered the many terms that remained. When appropriate, single expressions were combined into more encompassing ones; for instance, the idea of "exploitation of sources" implies the set of practices to extract water from aquifers, and concerns for availability and scarcity. As an additional example, the idea of "management technologies" encompasses all types of technologies and artefacts, including desalting plants, recharging operations, wells, waterwheels, small dams, gabions, or reuse. In the end, key expressions were those that exhibited the highest frequencies. That is why 18 essential characteristics make up the final list, as shown in Table 1.

Table 1. Main expressions representing water-use governance in SQR

\begin{tabular}{|c|c|c|}
\hline Key & Name & Description \\
\hline Agrib & Agribusiness sector & $\begin{array}{l}\text { Local and transnational, exporting agro-producers and } \\
\text { corporations }\end{array}$ \\
\hline AgrTech & $\begin{array}{l}\text { Agriculture } \\
\text { techniques }\end{array}$ & $\begin{array}{l}\text { Technological improvements: greenhouses, fertilisers, and } \\
\text { shade nets cultivation }\end{array}$ \\
\hline CEA & $\begin{array}{l}\text { BC commission on } \\
\text { water }\end{array}$ & Monitors water services throughout the state \\
\hline CESPE & $\begin{array}{c}\text { Ensenada commission } \\
\text { of public services }\end{array}$ & $\begin{array}{l}\text { Administers water services and infrastructure in the } \\
\text { municipality of Ensenada }\end{array}$ \\
\hline CNA & $\begin{array}{l}\text { National commission } \\
\text { on water }\end{array}$ & Generates and deploys national water policy \\
\hline Cotas & $\begin{array}{l}\text { San Quintin Technical } \\
\text { Committee on } \\
\text { Underground Water }\end{array}$ & $\begin{array}{c}\text { Regional committee, where government and local water- } \\
\text { users co-ordinate on the use of the aquifer }\end{array}$ \\
\hline Elites & Influential groups & $\begin{array}{l}\text { Economic and political groups influencing policies and } \\
\text { management of water usage }\end{array}$ \\
\hline Envnmst & $\begin{array}{l}\text { Environmentalist } \\
\text { groups }\end{array}$ & $\begin{array}{c}\text { Organisations whose main objectives spin around } \\
\text { protection of biodiversity and conservation of natural } \\
\text { resources }\end{array}$ \\
\hline
\end{tabular}




\begin{tabular}{|c|c|c|}
\hline Exploit & $\begin{array}{l}\text { Water exploitation } \\
\text { actions }\end{array}$ & $\begin{array}{l}\text { Exploitation practices and concerns on availability and } \\
\text { scarcity }\end{array}$ \\
\hline FedMgmt & Federal management & $\begin{array}{l}\text { Concessions, over-concessions, assignations, } \\
\text { apportionment, and management of water }\end{array}$ \\
\hline LegalFrwk & Legal framework & Regulatory directives on water administration \\
\hline LocMgmt & Local management & $\begin{array}{c}\text { Local services: piped, drinkable water, sanitation, } \\
\text { drainage }\end{array}$ \\
\hline LocResid & Local residents & Citizenry and communitarian leaders \\
\hline MgmtTech & $\begin{array}{l}\text { Management } \\
\text { technologies }\end{array}$ & $\begin{array}{l}\text { Technological resources, as desalting plants, recharging, } \\
\text { wells, waterwheels, small dams, gabions, and reuse of } \\
\text { water in industry, urban green areas, and agriculture }\end{array}$ \\
\hline Pollut & Pollution & $\begin{array}{l}\text { Soil and water sources damages due to fertilisers, } \\
\text { lixiviates, saline intrusion }\end{array}$ \\
\hline Sagarpa & $\begin{array}{l}\text { Ministry of } \\
\text { agriculture, cattle, } \\
\text { fishery, and food }\end{array}$ & $\begin{array}{l}\text { Deploys public policies in regards of the primary sectors } \\
\text { of economy }\end{array}$ \\
\hline Sefoa & $\begin{array}{l}\text { BC ministry of } \\
\text { agriculture }\end{array}$ & $\begin{array}{c}\text { Promotes and monitors the state policy on agriculture and } \\
\text { cattle }\end{array}$ \\
\hline Semarn & $\begin{array}{l}\text { Ministry of the } \\
\text { environment and nat. } \\
\text { res. Includes the } \\
\text { Federal attorney } \\
\text { (Profepa) }\end{array}$ & $\begin{array}{l}\text { Implements policies to protect and conserve the } \\
\text { environment and the natural resources. Inspects obedience } \\
\text { to environmental regulation, and enforces the law }\end{array}$ \\
\hline
\end{tabular}

\section{Cluster analysis}

The results shown in Figure 2 reveal that, at a similarity degree of nearly 0.7 , the main expressions arrange themselves into three well-defined groups: (1) Elites, AgrTech, and Agrib; (2) LocMgmt, LegalFrwk, CNA, Exploit, CESPE, and at further distance Semarn; (3) FedMgmt, Cotas, and Pollut. It is noteworthy that the group of environmentalist actors (Envnmst) appears as the most distant in the study.

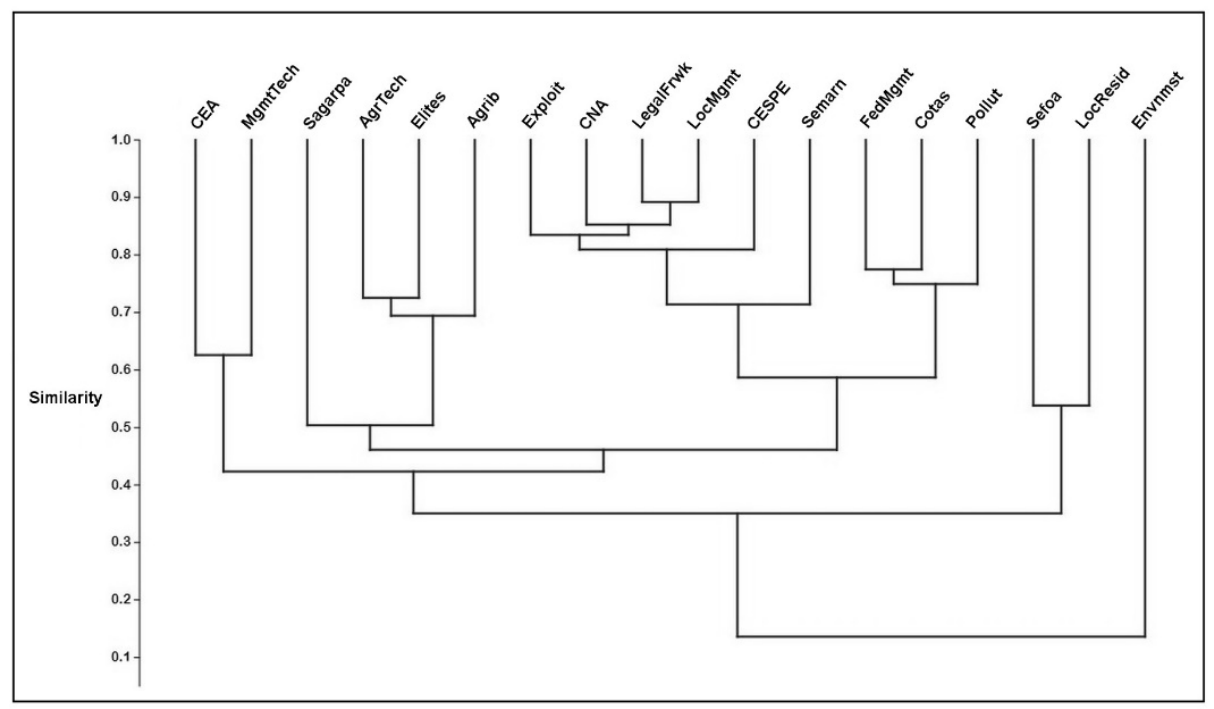

Figure 2. Plot of Cluster Analysis 


\section{Network analysis}

Figure 3 shows the relationships of characteristics as nodes displayed according to their relevance. The network decomposes into sub-networks or communities, differentiable in the figure by shades of grey via the Gephi's Modularity algorithm. The weights of the linkages or edges were useful in highlighting the most relevant, interconnected nodes within the communities.

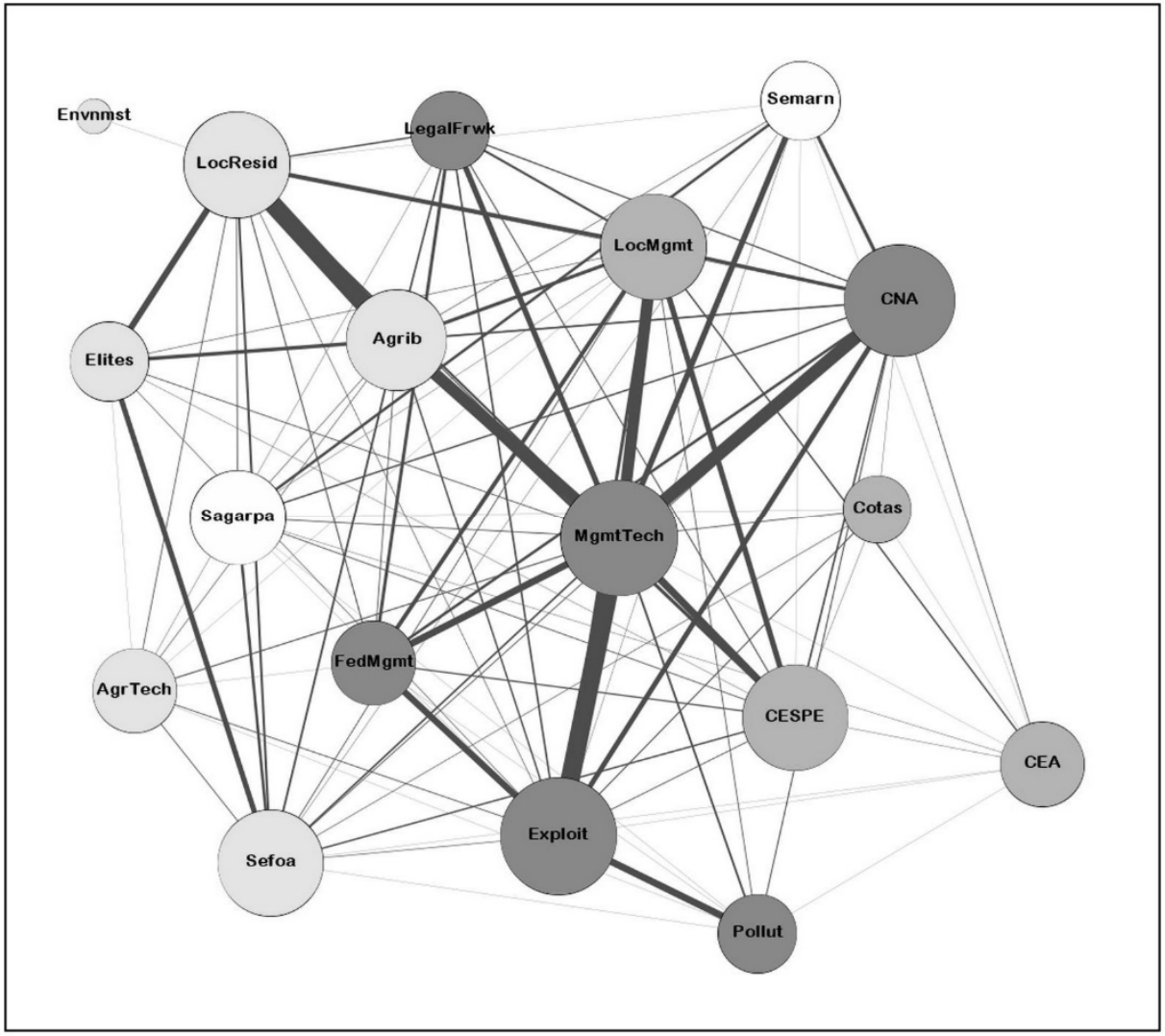

Figure 3. Networks of relevant characteristics in SQR

It is observable that one sub-network contains the nodes of Elites, AgrTech, Agrib, LocResid, Sefoa, and Envnmst, although the latter at the greatest distance. The nodes CNA, MgmtTech, Exploit, Pollut, FedMgmt, and LegalFrwk define another community, and the nodes CESPE, LocMgmt, CEA, and Cotas compose a third sub-network.

In addition to the described arrangements, it is notable that eight nodes have the greatest relevance to the net; these are CNA, CESPE, Agrib, LocResid, MgmtTech, FedMgmt, Exploit, and Pollut. 


\section{Discussion}

\section{TMNet method}

The textual analysis revealed that 18 characteristics amount to the governance of water use in SQR. The multivariate CA illustrates, firstly, the ties established by elites and agribusiness to water use, and the importance this group gives to agriculture technologies. Secondly, it shows the close relation between the characteristics of local management and the legal framework, which could not be otherwise given the limited attributions of the local bureaucracies; that is to say, in regard to stipulations of federal control, local management is legally constrained. It is also apparent that the federal CNA and the state CESPE cluster at this level, and that their leading commitment to exploitation of resources appears in the same group. Finally, the cluster including federal management and the San Quintin Cotas seems normal given that the committee is dependent on federal decision-making; however, what draws attention here is the accompanying pollution of water wells and aquifers, which in fact is one of the alleged concerns of Cotas.

With regard to network analysis, it is feasible to argue that the nodes CNA, CESPE, Agrib, LocResid, MgmtTech, FedMgmt, Exploit, and Pollut define with clarity the governance of water use in SQR. In the first place, CNA and CESPE are the main organisations in charge of water administration and management; in the second, the agribusiness sector and the local residents are the users of the resource. It follows that the management of technologies and technological fixes correspond to the prevailing economic rationale. Finally, the network underscores the consequences of such orientation: exploitation of available water up to the point of overexploitation and pollution.

\section{Dubious institutional workings}

The study exposed that key public establishments and actors remain attached to the mainstream rationale of profit as well as to the red tape of governmental bureaucracy, pushing water reserves to risky limits. Three aspects negatively affect the governance of water use: the utilization of government function for the benefit of interest groups; the recurrent institutional shortcomings before social and environmental matters; and a state of decision-making inertia created by the absence of key public offices from their responsibilities in this regard.

\section{Government benefits influential interest groups}

The institutional framework allows the accommodation of the federal CNA to a market-oriented model that draws the agribusiness sector closer to the agency. The regulation entitled CNA provides authority to give agribusiness advantages regarding water management (Gov. of Mexico, 
2012a, b). CNA and the state CESPE accommodate a managerial orientation, perceiving that their duties are the granting of concessions, assignments, and extensions of infrastructure, which certainly implies the politically oriented vice of favouring the wealthy. In this way, agro-producers receive subsidies to acquire machinery for extraction of further volumes of water from aquifers.

Another bureaucratic organisation, Sefoa, which is in charge of agricultural activity in Baja California, is a target for critics due to its role in the distribution of water and financial incentives. Sefoa, like CNA and CESPE, seems oriented towards elite political and economic interests. One explanation of this behaviour is that the owners of at least two of the richest ranches in SQR have been heads of Sefoa in successive administrative periods. The construction of a desalinization plant illustrates this pattern. In 2009, the state government approved the construction of a plant that would produce 60,000 cubic metres of drinkable water per day; nevertheless, Sefoa warned that $70 \%$ of the processed volume would be oriented towards agribusiness (Cruz-Aguirre, 2009). The authority did not reveal any technical study or any consultation of the people to support this decision. The close bond between the entrepreneurs and the political sectors is evident; politicians and public servants are associates of some ranches in the region.

\section{Institutional failures on Social and environmental matters}

Whereas the managerial approach brings advantages to one sector, it creates parallel disadvantages for others. Agribusiness long ago made remarkable improvements to production processes. Starting with on-field extensive agriculture in the second half of the 20th century, the technological package now includes greenhouses and computer-assisted monitoring and cultivation of crops. These highly technical processes enable the creation of international-market quality products, which allows agribusinesses to export them rather than distributing them to the internal market (Zlolniski, 2011; Gov. of Ensenada, 2014). In addition, the agro-producers successfully implemented the use of desalinization plants to process underground water. With impeccable pragmatism, they trust technological fixes to solve problems and continue in business: once they deplete the salty aquifers, the next step is the desalinization of seawater.

The status of several sectors of the population demonstrates the other side of the coin; they still lack general and domestic services, and the inhabitants endure hardships trying to satisfy their needs. Most of the people are regularly served less and low-quality water, and despite population increase converting rural areas into urbanised ones, the authorities offer meagre infrastructure and services, worsening the conditions of poor and 
indigenous settlements, where even the minimum standards of wellbeing are absent.

In this scenario, the relationship between the local residents and the agribusiness sector is strong in the sense that both are interested in achieving the same goal: getting water. However, this relationship is not positive; while the entrepreneurs want to have more volume for agriculture, the local residents struggle to get enough water to fulfil their essential requirements.

\section{Key bureaucracies are absent of the decision-making process}

Despite their formal mandates, the federal ministries of environment and agriculture are absent from the decision-making process regarding water conservation and management. The former (Semarnat), in charge of promoting natural resource care and sustainability, keeps a regrettable distance from the relevant actors, and seems incapable of leading any change in profit distribution that might allow for mitigation of environmental damage. The latter (Sagarpa), in charge of operating the policies on agriculture, cattle, and fisheries, appears less relevant than Sefoa, its partner at the state level. Plainly, given the laser-like focus on promoting the profitability of private corporations at the federal and state levels by powerful offices such as those of Economy, Finance, CNA and Sefoa, the ineffectiveness of Semarnat and Sagarpa seems understandable. However, the role they play is not justifiable, for they have clear legal mandates and, at either federal or state levels, they must act as partners rather than as subordinates. Unless the centralised, for profit orientation stops determining the decision-making process around water use, the negative panorama will not change in SQR. Increased overexploitation, salinization, and pollution of water sources, as well as the low quality of water allotted for domestic purposes, will continue to be a part of daily life.

\section{Institutional reform for better governance}

The understanding of water and natural hydrologic systems as simple economic goods is widely questioned. Scholars agree that planning and projects avoid the debate on water as a social and ecological asset that fulfils vital functions; also, they agree that the profits-over-all-else approach is at the root of ecosystem degradation. Sewage-polluted rivers, dry riverbeds, and polluted, overexploited or saltier water sources are but a few of the negative manifestations (Arrojo et al., 1997, p. 172; Molle \& Wester, 2009, p. 17). Moreover, because the world economy responds primarily to market signals, rivers and watersheds face threats related to the "modes of appropriation of terrestrial biomass by capitalism" (Toledo, 2006, p. 10).

Following the mainstream rationale, in recent decades Mexico has embraced market-oriented rules and policies, wiping out the non-economic 
dimensions of water. Therefore, hydrologic resources have deteriorated dramatically, generating harmful effects not only on ecosystems but also in the society's living conditions. Consequently, the exultant official discourse of welfare and growth seems inaccurate.

SQR is not an exception to the rule. There, the production-oriented perspective dominates; the mainstream rationale only praises the profitable dimension of water, instead of its importance as a public good, much less as a human right. In this context, government support to the wealthy is to the detriment of the impoverished and neglects the critical conditions of natural resources (Zlolniski, 2011, pp. 574-575; Hernández, 2000, pp. 188-189) in a manner that is not only inequitable, but also irrational.

Considering how important context may be (Honadle, 1999), it happens that in SQR, actors prefer to circumvent or minimise it. First, whether policies applied correctly in one case are inadequate in another is a matter of lesser importance to the central government; the directive of granting permits and concessions to private business is the same in all of Mexico. Second, the principle that context where problems unfold shapes the processes used to formulate policies is weakly considered; this may be the reason why the owners of some of the richest ranches have been appointed to head the ministry of agriculture in Baja California. Under such a scenario, it is clear that these institutions are ineffective and inappropriate.

Dubious institutional operation in SQR implies that federal and state governments generate, whether by duty or voluntarily, inequality, social confrontation, and environmental decline. The current water use rationale and organisational framework demand a reorientation of purpose, and there is a need to present alternatives to the legal and administrative framework to resolve this state of affairs, improving governance through the betterment of laws and responsible institutions. In brief, questionable practices must recede in favour of effective governance.

To achieve social and environmental sustainability in Mexico, and certainly in SQR, one starting point would be to elevate the concept of water to the level of being an integral (economic, public, and human) asset. The idea is certainly nothing new; rather, it only means congruent compliance of Mexico with international agreements, including the UN Covenant on Economic, Social and Cultural Rights and the UN Resolution on the Human Right to Water and Sanitation. To achieve sustainability, it is necessary to thoroughly review national policy, and address two major issues: firstly, there must be access to water for all in sufficient quality and quantity; and secondly, there must be a decisive halt to overexploitation. It is also desirable to revise the national constitution to guarantee the human rights to water, sanitation, and security, and to boost intergovernmental and societal collaboration towards integral development. 
Constitutional reform-guaranteeing mechanisms for the coordination, concurrence, and subsidiary of the federal and local governments, as well as dialogue between authorities and the citizenrycompels undertaking a revision of the secondary regulatory and organisational framework with respect to water, the environment, rural development, and administration. Centralisation would feasibly give way to decentralisation, and intergovernmental collaboration would minimise the threat of fragmentation of public establishments.

The findings in the SQR case help to thoroughly explain the complexity of an issue that, unsurprisingly, mirrors the prevailing institutional project, in which elite politicians and entrepreneurs intermingle and exercise control over natural resources. There is sufficient knowledge of the causes and delimitations of ecological problems around water use in the area, and there is access to technical pathways to resolve them; however, the fact that these problems have persisted for years indicates that their roots and solutions are of another type. In fact, only in the political realm is it possible to understand the problems.

To overcome any pernicious and significant inertia or the reforms proposed at the national level, a regional agenda of short- and medium-term goals that positively affects the management of natural resources and the quality of life in the region should be formulated. First, public servants must consistently obey and enforce the law with impartiality; second, government representatives at federal and local levels must coordinate their actions in favour of the people, taking into account that their first duty is to serve all, not only influential groups. A third aspect is that bureaucrats in charge of social and environmental organisations must adhere to their legal mandates, thus standing up to powerful interests and integrating common goals in the decision-making process when possible. Finally, state and municipal authorities must promote the creation of harmonious bonds with community members to advance the sustainability agenda.

Jointly, the proposals announce a comprehensive, overarching approach to improved water use governance in SQR, in which long-term equilibrium among economic, social, and environmental objectives seems viable. If these conditions were taken seriously, the results would be less costly from any perspective.

\section{Conclusion}

Water use governance in Mexico is a contentious issue. The aims of sustainable use are constrained not only by the physical characteristics of the country, but also (and perhaps primarily) by dubious institutional workings. The actions of bureaucratic organisations expose ineffective planning and management because their centralised design-water policy and regulation 
being a federal domain-hinders the capability of state and local governments to take the lead in decision-making. SQR mirrors the national state of affairs, although in the region the situation turns out to be even more pressing due to its arid conditions and the extreme exploitation of natural resources for agriculture. The resulting environmental damage and social concerns paint a pessimistic picture of the viability of the fragile ecosystem.

Examination of the water-use conundrum in SQR via the TMNet method uncovered the main concepts and characteristics, the roles and preferences of actors, and the relations established among the relevant components. It was useful to examine the current governance scheme and define alternatives by which the local population and natural resources become significant.

A proposal of institutional reform in SQR should overcome the negative aspects of the governance of water use that lean towards dubious practices. Attention must be paid to three factors: the use of government function for the benefit of influential interest groups; the contrasting relationship between successful agribusiness and ignored inhabitants, plus the decimated environment; and a state of decision-making inertia created by the absence of key public offices from their responsibilities in this regard. Harmonisation of these aspects would contribute substantially to the betterment of governance-in other words, a balance among economic, social, and environmental interests. Improving governance of water use implies a shift in public policy and institutional planning; the challenge, thus, is to transcend economic and power control towards more encompassing interests. This seems to be a promising route to sustainability.

\section{References:}

1. Arrojo, P., Sánchez, J., \& Bielsa, J. (1997). Fundamentos para una gestión del agua coherente con un modelo de desarrollo sostenible. In: P. Molina, ed. Actas del I y II seminario del agua. España: Instituto de Estudios Almerienses, 167-190.

2. CNA. (2002). Determinación de la disponibilidad de agua en el acuífero San Quintín, estado de Baja California. Mexico: Conagua. Available from: http://aguaenmexico.org/images/estados10enero/Guanajuato/Articulo s/Valle\%20de\%20Leon.pdf [Accessed September 2016].

3. CNA. (2014). Estadísticas del Agua en México 2014. Mexico: Conagua. Available from: http://www.conagua.gob.mx/CONAGUA07/Publicaciones/Publicaci ones/EAM2014.pdf [Accessed September 2016]. 
4. Cejudo, G. (2008). Explaining change in the Mexican public sector: the limits of New Public Management. International Review of Administrative Sciences, 74(1), 111-127.

5. Coplade. (2013). Apuntes de población de Baja California. Mexicali: Gob. de B.C. Available from: http://www.copladebc.gob.mx/publicaciones/2013/Apunte $\% 20$ Poblac ion $\% 20 \mathrm{de} \% 20 \mathrm{los} \% 20$ municipios $\% 20 \mathrm{de} \% 20 \mathrm{Baja} \% 20$ California $\% 202$ 010-2030.pdf [Accessed February 2017].

6. Cruz-Aguirre, J. (2009). Mal manejo del agua. En los valles de San Quintín y Guadalupe. Zeta, 1842, 23 July.

7. Cruz-Souza, F. (2007). Empoderamiento y sostenibilidad en el desarrollo rural: trampas de la racionalidad productivista. Anduli, 7, 91-104.

8. Eakin, et al. (2011). Public Sector Reform and Governance for Adaptation: Implications of New Public Management for Adaptive Capacity in Mexico and Norway. Environmental Management, 47, 338-351.

9. Evans, P. (1989). Predatory, Developmental, and Other Apparatuses: A Comparative Political Economy Perspective on the Third World State. Sociological Forum, 4(4), 561-587.

10. Garavito, L. (2010). Redes sociales por el agua en la Cuenca de México. In: X Congreso anual de investigación sobre el tercer sector: Sociedad civil y ciudadanía en el cambio social. Puebla: BUAP, 18-47.

11. Gov. of Baja California. (2003a). Programa de desarrollo urbano de los centros de población San Quintín-Vicente Guerrero. Mexicali: Periódico Oficial.

12. Gov. of Baja California. (2003b). Programa de Desarrollo Regional del Estado de Baja California 2003-2007. Available from: http://www.cecytebc.edu.mx/spf/compendio_normatividad/Programa s\%20(Nivel\%207)/Programas\%20Especiales/P.\%20Regional\%20de \%20Baja\%20California.pdf [Accessed September 2016].

13. Gov. of Baja California. (2007). Programa de Ordenamiento Ecológico de la Región de San Quintín. Mexicali: Periódico Oficial, 15 June.

14. Gov. of Baja California. (2008). Programa de desarrollo para la Región San Quintín 2008-2013. Mexicali: Gob. de B.C.

15. Gov. of Baja California. (2014). Ley de Asociaciones PúblicoPrivadas para el Estado de Baja California. Mexicali: Periódico Oficial, 42, T. CXXI, Sec. I, 22 August.

16. Gov. of Baja California. (2015). Respuesta a solicitud de información 708/TC/2015.

from: 
http://www.congresobc.gob.mx/contenido2/Transparencia/Transpare ncia/rrespuestas2012/708.pdf [Accessed February 2017].

17. Gov. of Baja California. (2016). Ley del Agua para el estado de Baja California. Mexicali: Periódico Oficial, 55, T. CXXIII, Sec. I, 30 December.

18. Gov. of Ensenada. (2011). Proyecto Estratégico Agricultura Protegida. Available from: http://www.inca.gob.mx/territorial/proyectosterritorial/bc/PET\%20En senada.pdf [Accessed September 2016].

19. Gov. of Ensenada. (2014). Programa Municipal Concurrente para el Desarrollo Rural Sustentable de Ensenada. Available from: http://imipens.org/IMIP_files/PMC-DRSE\%202014_01_06.pdf [Accessed August 2016].

20. Gov. of Mexico. (2012a). Ley de Aguas Nacionales. Mexico: DOF, 8 June.

21. Gov. of Mexico. (2012b). Decreto que reforma, adiciona y deroga diversas disposiciones del Reglamento Interior de la Comisión Nacional del Agua. Mexico: DOF, 12 October.

22. Gov. of Mexico. (2012c). Ley de Asociaciones Público Privadas. Mexico: DOF, 16 January.

23. Greer, J., \& Singh, K. (2000). A Brief History of Transnational Corporations. from:

https:/www.globalpolicy.org/empire/47068-a-brief-history-oftransnational-corporations.html [Accessed February 2017].

24. Hernández, C. (2000). Prácticas ambientales y migración indígena. Caso de los mixtecos en el Valle de San Quintín. Master Thesis. El Colegio de la Frontera. Available from: http://www.colef.mx/posgrado/wp-content/uploads/2009/07/TESISHernández-Santiago-Cuitláhuac.pdf [Accessed August 2016].

25. Honadle, G. (1999). How context matters: linking environmental policy to people and place. West Hartford, Conn: Kumarian Press.

26. Hurtado, J. (2012). Iniciativa que reforma y adiciona diversas disposiciones de la Ley de Aguas Nacionales. Legislatura Federal. Available from: http://www.youtube.com/watch?v=4Z8RZeYauYM [Accessed August 2016].

27. INEGI. (2015). México en cifras. Available from: http://www3.inegi.org.mx/sistemas/mexicocifras/default.aspx? $\mathrm{src}=48$ $7 \& \mathrm{e}=2$ [Accessed August 2016].

28. Lizárraga, J. (1997). Mexican Agribusiness and the U.S. Food System. Urban Ecologist. Available from: http://www.sustainablecity.org/articles/mexican.htm [Accessed August 2016]. 
29. Molle, F., \& Wester, P. (2009). River Basin Trajectories: an Inquiry into Changing Waterscapes. In: F. Molle, \& P. Wester, eds. River Basin Trajectories. Societies, Environments and Development. Oxfordshire: CAB International, 1-19.

30. Mussetta, P. (2013). El agua en discordia: balance cualitativo en Latinoamérica. Revista Gestión y Ambiente, 16(1), 113-127.

31. Ngosso, T. (2013).The Right to Development of Developing Countries: An Argument against Environmental Protection? Public Reason, 5 (2), 3-20.

32. Oka, R., \& Kuijt, I. (2014). Greed Is Bad, Neutral, and Good: A Historical Perspective on Excessive Accumulation and Consumption. Economic Anthropology, 1(1), 30-48.

33. Riemann, H. (2015). La región agrícola Camalú-El Rosario y sus recursos hídricos. In: H. Riemann, ed. El agua en la región agrícola Camalú-El Rosario, Baja California. Un recurso sobreexplotado con repercusiones sociales y ambientales. Mexico: Red Nacional de Investigación Urbana, 11-27.

34. Ruiz, G. (2014). Protestan por falta de agua en San Quintín. Available from: http://zetatijuana.com/2014/06/03/protestan-porfalta-de-agua-en-san-quintin/ [Accessed August 2016].

35. Santes-Álvarez, R. (2015a). Gobernanza y medio ambiente: experiencias de actuación institucional en la frontera México-Estados Unidos. In: L. Ruelas, A. Travieso and O. Sánchez, eds. Gobernanza ambiental. Teoría y práctica para la conservación y uso sustentable de los recursos. Mexico: Plaza y Valdés-Colver, 237-258.

36. Santes-Álvarez, R. (2015b). Aspectos que definen la gobernación del uso de agua en Región San Quintín. In: H. Riemann, ed. El agua en la región agrícola Camalú-El Rosario, Baja California. Un recurso sobreexplotado con repercusiones sociales y ambientales. Mexico: Red Nacional de Investigación Urbana, 95-115.

37. Santes-Álvarez, R. (2016). Gobernación del uso del agua en un territorio en crisis: Región San Quintín, en Baja California. In: O. Contreras and $\mathrm{H}$. Torres, eds. Medio ambiente y sociedad. $5^{\circ}$ Congreso Nacional de Ciencias Sociales. Guadalajara: Comecso-U. Guadalajara, 748-758.

38. Santos, C., \& Villarreal, A. (2005). Uruguay: la democracia directa en la defensa del derecho al agua, In: Balanyá et al., eds. Por un modelo público de agua. Triunfos, luchas y sueños. España: El Viejo Topo, 179-184.

39. Schlesinger, S. (2008). New wood for old fires. The fever for agrifuels. Rio de Janeiro: ActionAid. 
40. Segrelles, J. (2001). Problemas ambientales, agricultura y globalización en América Latina. Scripta Nova, 92 (1 July). Available from: http://www.ub.edu/geocrit/sn-92.htm [Accessed November 2013].

41. Shah, T., Scott, C., \& Buechler, S. (2004). Water sector reforms in Mexico. Lessons for India's new water policy. Economic and Political Weekly, January 24, 361-370.

42. Spangenberg, J. (2006). Introduction. Society and its products. In: I. Zbicinski, J. Stavenuiter, B. Kozlowska and H.P.M. van de Coevering, eds. Product Design and Life Cycle Assessment. Uppsala: The Baltic University Press, 17-28.

43. Talavera, P. (2014). Economicism and Nihilism in the Eclipse of Humanism. Humanities, 3. Available from: http://www.mdpi.com/2076-0787/3/3/340/pdf [Accessed July 2016].

44. Toledo, A. (2006). Agua, hombre y paisaje. Mexico: INE-Semarnat.

45. United Nations. (1992). The Dublin Statement on Water and Sustainable Development. Available from: http://www.undocuments.net/h2o-dub.htm [Accessed August 2016].

46. United Nations. (2003). General Comment No. 15 (2002). The right to water (arts. 11 and 12 of the International Covenant on Economic, Social and Cultural Rights). Available from: http://www.un.org/waterforlifedecade/human_right_to_water.shtml [Accessed June 2014].

47. United Nations. (2010). The human right to water and sanitation. UN Resolution A/RES/64/292, 3 August. Available from: http://www.un.org/waterforlifedecade/human_right_to_water.shtml [Accessed June 2014].

48. Velasco, L., Zlolniski, C., \& Coubés, M. (2014). De jornaleros a colonos: residencia, trabajo e identidad en el valle de San Quintín. Tijuana: El Colef.

49. Wengert, N. (1971). Political and Social Accommodation: The Political Process and Environmental Preservation. Natural Resources Journal, 11(3), 437-446.

50. Wilder, M. (2010). Water Governance in Mexico: Political and Economic Apertures and a Shifting State-Citizen Relationship. Ecology and Society, 15(2): 22. Available from: http://www.ecologyandsociety.org/vol15/iss2/art22/ [Accessed September 2011].

51. Zlolniski, C. (2011). Water Flowing North of the Border: Export Agriculture and Water Politics in a Rural Community in Baja California. Cultural Anthropology, 26 (4), 565-588. 
52. Zomosa, A. (2007). Mexican water reform: Paradoxes of institutional development, integrative management, and modernization. IDEAS Journal. Available from: http://fletcher.tufts.edu/ /media/Fletcher/Microsites/CIERP/Ideas/3_i deas/ZomosaSignoretAndrea_MexicoWater.pdf [Accessed July 2016].

53. Zúñiga, E., et al. (2012). Daño Genético y Exposición a Plaguicidas en Trabajadores Agrícolas del Valle de San Quintín, Baja California, México. Revista de Salud Ambiental, 12(2). Available from: http://ojs.easyapps.es/index.php/rsa/article/download/328/280 [Accessed May 2016]. 